\title{
Analisis Tingkat Kepuasan Penumpang Terhadap Jasa Pelayanan Penyeberangan Menggunakan Metode Logika Fuzzy Servqual Pada PT. ASDP Indonesia Ferry Cabang Sibolga
}

\author{
Rini Simanullang ${ }^{1 *}$, Murni Marbun ${ }^{2}$ \\ ${ }^{1,2}$ STMIK Pelita Nusantara \\ Jl. Iskandar Muda No. 1 Medan 20154 Indonesia \\ Corresponding author's e-mail: rinisimanullang9@gmail.com
}

\begin{abstract}
Abstrak-Pelayanan dapat dikatakan baik, apabila pelayanan tersebut dapat memenuhi kepuasan penumpang, kepuasan tercapai jika pelayanan yang diterima penumpang dapat melebihi apa yang diharapkan. Dalam Logika Fuzzy pengambilan keputusan dilakukan dengan sistem inferensi yang disebut dengan sistem inferensi fuzzy yang merupakan proses pengambilan kesimpulan berdasarkan penalaran Logika Fuzzy. Diantara berbagai model pengukuran kualitas pelayanan (servqual), servqual merupakan metode yang paling banyak digunakan karena frekuensi penggunaannya yang tinggi, Kriteria-kriteria untuk mengukur kepuasan penumpang, yaitu bentuk fisik, kehandalan, tanggapan, empati, jaminan. Dari hasil perhitungan nilai Servqual (gap) per dimensi, yang menempati ranking pertama adalah dimensi Reliability sebesar 7.65, seperti halnya pada hasil perhitungan per kriteria dimana tiga kriteria yang menjadi prioritas merupakan bagian dari dimensi Reliability. Untuk urutan kedua yaitu Tangibles sebesar 0.17 , urutan ketiga yaitu dimensiAssurance -0.05 urutan keempat yaitu empaty sebesar 0.20, dan yang terakhir atau urutan kelima yaitu Responsivenesssebesar -11.48. Sistem ini dirancang untuk analisis tingkat kepuasan penumpang pada PT. ASDP Cabang Sibolga dengan menggunakan bahasa pemograman PHP. Pengelolalaan data menggunakan database Mysql.

Kata kunci: jasa, kuisioner, nilai Servqual, kriteria kepuasan, Logika Fuzzy
\end{abstract}

Abstract - Service can be said to be good, if the service can meet passenger satisfaction, satisfaction is achieved if the service received by passengers can exceed what is expected. In Fuzzy Logic, decision making is done by using an inference system called the fuzzy inference system which is a process of making conclusions based on Fuzzy Logic reasoning. Among the various models for measuring service quality (servqual), servqual is the most widely used method because of its high frequency of use. The criteria for measuring passenger satisfaction are physical form, reliability, response, empathy, assurance. From the calculation of the Servqual value (gap) per dimension, the first rank is the Reliability dimension of 7.65, as is the case with the calculation per criterion where the three priority criteria are part of the Reliability dimension. For the second order, Tangibles is 0.17 , the third order is the Assurance dimension -0.05 , the fourth order is empathy at 0.20 , and the last or fifth order is Responsiveness of -11.48. This system is designed to analyze the level of passenger satisfaction at PT. ASDP Sibolga Branch using the PHP programming language. Data management using the MySQL database.

Keywords: service, questionnaire, Servqual value, satisfaction criteria, Fuzzy Logic

\section{Pendahuluan}

Tingkat kepuasan penumpang terhadap pelayanan yang diberikan dapatdilihat dari penggunaan teknologi yang canggih, waktu yang efisien, sarana dan prasaranapelabuhan yang memadai serta perawatan yang baik [1]. PT.ASDP Cabang Sibolga merupakan perusahaan jasa angkutan penyeberangan dari pelabuhan Sibolga menuju Kepulauan Nias. Adapun pelayanan yang diberikan yaitu kemudahan untuk mendapatkan tiket, informasi mengenai jadwal keberangkatan dan kedatangan kapal, pelayanan bagasi bagi penumpang, menyediakan kafe untuk melayani kebutuhan makanan dan minuman bagi penumpang. Selain pelayanan PT.ASDP juga menyediakan fasilitas yaitutempat parkir, mushola, kamar mandi, kursi sebagai tempat peristirahatan penumpang, tempat penjualan tiket, ruang tunggu penumpang dan pengantar atau penjemput.

Logika Fuzzy adalah suatu cara yang tepat untuk memetakan suatu ruang input dalam suatu ruang output dan memiliki nilai yang berlanjut [2]. Teori himpunan Fuzzy, peranan derajat keanggotaan sebagai penentu keberadaan elemen dalam suatu himpunan sangatlah penting. Nilai keanggotaan atau derajat keanggotaan menjadi ciri utama dalam penalaran dengan Logika Fuzzy [3]. Logika yang menggunakan konsep sifat kesamaran dengan banyak kebenaran yang dinyatakan dalam bilangan real dalam selang [0,1]. Sistem Inferensi Fuzzy dapat dilakukan dengan menggunakan beberapa Metode yaitu Metode Mamdani, Metode Tsukamoto, Metode Sugeno, dan Metode Servqual (Service Quality).

Metode Servqual (Service and Quality) merupakan metode yang di gunakan untuk mengetahui kriteria- 
kriteria kualitas yang harus ditingkatkan kualitas pelayanannya berdasarkan gap yang terjadi antara persepsi dan harapan pelanggan [4]. Servqual dipandang memenuhi syarat validitas secara stastik metode servqual terdiri atas lima dimensi kualitas pelayanan yaitu : reliability (keandalan), assurances (jaminan), tangibles (bukti terukur), empathy (empati), responsiveness (daya tanggap). Penelitian ini mencoba mengintegrasikan serqvual dengan fuzzy dengan menggunakan metode ini diharapkan dapat menangkap bias dan subyektifitas yang terjadi pada saat mengumpulkan data melalui pengisian kuisioner [5].

Penelitian Analisis Kepuasan Pelanggan TravelMenggunakan Metode Fuzzy Service Quality mengukur kualitas pelayanan dapat menggunakan metode metode Fuzzy-Servqual yang digunakan untuk menentukan variabel kebutuhan pelanggan yang tidak terpenuhi dengan menghitung gap (kesenjangan) antara pelayanan yang diberikan dengan harapan pelanggan sebagai voice of costumer [6]. Kriteria yang menjadi prioritas utama untuk diperbaiki dan peningkatan kualitas pelayanan jasa adalah dimensi Tangibles. Penelitian metode Fuzzy Servqual. Dalam Mengukur Kepuasan Pasien Terhadap Kualitas Layanan BPJS Kesehatan. Kurangnya kualitas pelayanan menjadi salah satu kendala terhadap tingkat kepuasan pasien. Pihak rumah sakit juga sering kali kesulitan dalam mengukur kualitas pelayanannya [7]. Penelitian Implementasi Fuzzy Servqual Dalam Evaluasi Kualitas pelayanan penyuluh pertanian. Penelitian ini bertujuan mengukur kualitas pelayanan penyuluh pertanian pada UPT BPP Sukaraja dengan menggunakan metode fuzzy service quality (servqual) dengan pengelompokkan atributpertanyaan ke dalam lima kriteria dimensi pelayanan, yaitu dimensi tangibles (bukti langsung), reliability (keterpercayaan), responsiveness (ketanggapan), assurance (jaminan), dan empathy (empati) [8].

\section{Tinjauan Pustaka}

\subsection{Logika Fuzzy}

Dasar logika fuzzy adalah teori himpunan fuzzy. Pada teori himpunan fuzzy, peranan derajat keanggotaan sebagai penentu keberadaan elemen dalam suatu himpunan sangatlah penting. Nilai keanggotaan atau derajat keanggotaan atau membership function menjadi ciri utama dari penalaran dengan logika fuzzy [9]. Pada himpunan tegas (crisp), nilai keanggotaansuatu item $\mathrm{x}$ dalam suatu himpunan A, yang sering ditulis dengan H_A (x), memiliki dua kemungkinan yaitu:

Satu (1), yang berarti bahwa suatu item menjadi anggota dalam suatu himpunan.

Nol (0), yang berarti bahwa suatu item tidak menjadi anggota dalam suatu himpunan.

2.2 Fungsi Keanggotaan (Membership Function)

Fungsi Keanggotaan (Membership Function) adalah suatu kurva yang menunjukkan pemetaan titik-titik input data ke dalam nilai keanggotaanya (seiring juga disebut dengan derajat keanggotaannya) memiliki interval antara 0-1. Salah satu cara yang dapat digunakan untuk mendapatkan nilai keanggotaan adalah dengan melakukan pendekatan fungsi [10]. Ada beberapa fungsi yang bisa digunakan:

a. Representasi linear

Pada representasi liner, pemetaan input kederajat keanggotaannya digambarkan sebagai suatu garis lurus. Ada dua keadaan himpunan fuzzy linear.

1. Representasi linear naik dimulai pada nilai domain yang memiliki derajat keanggotaan nol (0) bergerak kekanan menuju ke nilai domain yang memiliki derajat keanggotaan lebih tinggi.

2. Representasi Linear Turun merupakan kebalikan yang pertama. Garis lurus dimulai dari nilai domain dengan derajat keanggotaan tertinggi pada sisi kiri kemudian bergerak mrnurun kenilai domain yang memiliki derajat keanggotaan lebih rendah.

b. Reprsentasi Kurva Segitiga, kurva segitiga pada dasarnya merupakan gabungan antara 2 garis (linear).

\section{Metode Penelitian}

Tahap dalam penelitian adalah sebagai berikut:

a. Indentifikasi Masalah

Pada proses identifikasi masalah, peneliti mengadakan survey pendahuluan dan menentukan objek penelitian yang berkaitan dengan topik permasalahan penelitian pada PT.ASDP CabangSibolga.

b. Pengumpulan Data

Dalam pelaksanaan penelitian ini dibutuhkan dua jenis data yaitu Data Primer, mengumpulkannya secara langsung, dan Data Sekunder, diperoleh atau dikumpulkan dari berbagai sumber

c. Penerapan Metode

Pada proses penerapan algoritma, peneliti melakukan analisis kebutuhan sistem yang akan dikembangkan. Analisa penerapan algoritma menjelaskan tahap untuk menerapkan metode Fuzzy Servqual dalam proses 
penyelesaian masalah tersebut. Setelah itu peneliti menggambarkan alur algoritma sesuai sistem.

d. Analisa dan Perancangan

Pada tahap analisa dan perancangan system dilakukan perancangan sistem seperti apa yang akan dirancang.

e. Impelementasi Sistem

tahapan membangun system sesuai dengan rancangan sistem. Pada tahap ini, sistem dibangundengan menggunakan bahasa pemograman PHP dan Database Mysql dan sistem dibangun berbasis web.

\section{Hasil dan Pembahasan}

Kebutuhan fungsional dalam meganalisis tingkat kepuasan penumpang:

a. Sistem dapat menampilkan halaman kuesioner

b. Sistem dapat menampilkan hasil penilaian kuesioner

c. Sistem dihitung dengan menggunakan proses Fuzzy Service Quality (SERVQUAL).

d. Sistem dapat menampilkan hasil tingkat kepuasan penumpang pada tiap dimensi pernyataan

Metode Fuzzy Servqual merupakan metode yang digunakan untuk mengetahui kriteria-kriteria kualitas yang harus ditingkatkan kualitas pelayanannya berdasarkan gap yang terjadi antara persepsi dan harapan penumpang. Variabel Penelitian diperoleh berdasarkan pelayanan yang diberikan oleh Pihak PT. ASDP Cabang Sibolga pada penumpang yang menggunakan jasa pelayanan penyeberangan dan kemudian dikelompokkan berdasarkan lima dimensi servqual yaitu Tangibles, Reliability, Responsiveness, Assurance, dan Emphaty.

Penentuan fuzzyset dilakukan untuk menentukan skor yang harus diberikan oleh responden untuk setiap kriteria yang diajukan dalam kuesioner.

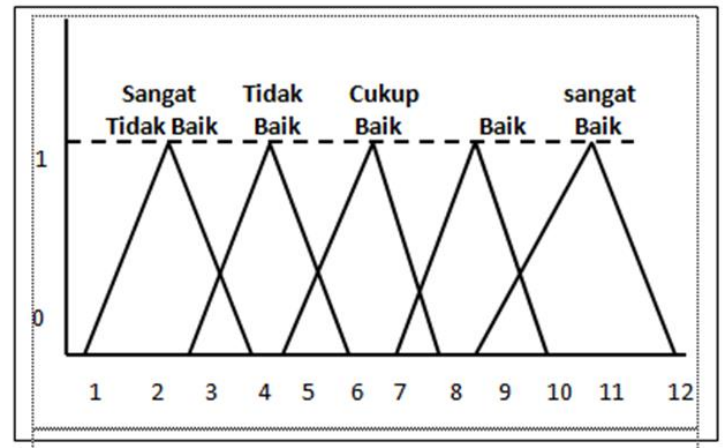

Gambar 1. Penentuan Fuzzy Set

Nilai yang digunakan dalam penentuan bobot (skor) di gunakan untuk mengetahui tingkat kualitas pelayanan dari perhitungan nilai fuzzyfikasi:

a. Kategori 1 = sangat tidak baik dengan skor 1,2,3,4

(meliputi jawabankuesioner Persepsi/Harapan yaitu Sangat Tidak Setuju/ Sangat Tidak Diharapkan).

b. Kategori 2 = Tidak Baik dengan skor 3,4,5,6

(meliputi jawaban kuesioner Persepsi/Harapan yaitu Tidak Setuju/Tidak Diharapkan).

c. Kategori 3 = Cukup Baik dengan skor 5,6,7,8

(meliputi jawaban kuesioner Persepsi/Harapan yaitu Setuju/Cukup Diharapkan).

d. Kategori 4 = Baik dengan skor 7,8,9,10

(meliputi jawaban kuesioner Persepsi/Harapan yaitu Setuju/Cukup Diharapkan).

e. Katagori $5=$ Sangat Baik dengan skor 9,10,11,12

(meliputi jawaban kuesioner Persepsi/Harapan yaitu Sangat Setuju/Sangat Diharapkan

Pada tahap Fuzzifikasi perhitungan fuzzifikasi dilakukan untuk mendapatkan nilai batas bawah (c), batas tengah (a), dan batas atas (b) yang merupakan nilai dari Triangular Fuzzy Number (TFN).

Nilai batas bawah $\left(\mathrm{c}_{\mathrm{i}}\right)$ :

$c i=\frac{b i * n 1+b 1 * n 2+\cdots b i(k-1) * n k}{n 1+n 2+\cdots+n k}$

Nilai batas tengah $\left(\mathrm{a}_{\mathrm{i}}\right)$ :

$a i=\frac{b 1 * n 1+b 1+n 2+\cdots b i(k-1) * n k}{n_{1+n_{2}+\cdots+n k}}$

Nilai batas atas $\left(b_{i}\right)$ 
$b i=\frac{\mathrm{bi} * \mathrm{n} 1+\mathrm{b} 1 * \mathrm{n} 2+\cdots+\mathrm{bi}(\mathrm{k}-1) * \mathrm{nk}}{n_{1+n_{2}+\cdots+n k}}$

Perhitungan tersebut dilakukan untuk mencari nilai Triangular Fuzzy Number (TFN) persepsi pada pernyataan P1. Untuk perhitungan selanjutnya dapat dilakukan dengan cara yang sama. Berikut ini adalah hasil dari nilai fuzzyfikasi persepsi.

Tabel 1. Hasil Fuzzifikasi Persepsi

\begin{tabular}{|c|c|c|c|}
\hline \multirow{2}{*}{$\begin{array}{c}\text { Kode } \\
\text { Pernyataan }\end{array}$} & \multicolumn{3}{|c|}{ TFN } \\
\hline P1 & 7.20 & A & B \\
\hline P2 & 6.80 & 8.30 & 10.20 \\
\hline P3 & 8.00 & 9.50 & 9.80 \\
\hline P4 & 8.20 & 9.70 & 11.00 \\
\hline P5 & 7.60 & 9.10 & 10.60 \\
\hline P6 & 7.20 & 8.70 & 10.20 \\
\hline P7 & 6.53 & 8.03 & 9.53 \\
\hline P8 & 7.87 & 9.37 & 10.87 \\
\hline P9 & 5.93 & 7.43 & 8.93 \\
\hline P10 & 7.20 & 8.70 & 10.20 \\
\hline P12 & 7.07 & 8.57 & 10.07 \\
\hline P13 & 7.47 & 89.67 & 10.47 \\
\hline P14 & 6.80 & 8.3 & 9.80 \\
\hline P15 & 7.13 & 8.03 & 9.53 \\
\hline P16 & 7.33 & 8.63 & 10.13 \\
\hline P17 & 7.27 & 8.77 & 10.33 \\
\hline P18 & 7.13 & 8.63 & 10.27 \\
\hline P19 & 7.07 & 8.57 & 10.13 \\
\hline P20 & 7.07 & 8.57 & 10.07 \\
\hline P21 & 6.33 & 7.83 & 9.33 \\
\hline P22 & 6.93 & 8.43 & 9.93 \\
\hline P23 & 7.80 & 9.3 & 10.80 \\
\hline P24 & 7.33 & 8.83 & 10.33 \\
\hline P25 & 7.93 & 9.43 & 10.93 \\
\hline P27 & 7.73 & 9.23 & 10.73 \\
\hline P26 & 8.13 & 9.63 & 10.13 \\
\hline
\end{tabular}

Tabel 2. Hasil Fuzzifikasi Harapan

\begin{tabular}{|c|c|c|c|}
\hline \multirow{2}{*}{$\begin{array}{c}\text { No } \\
\text { Pernyataan }\end{array}$} & \multicolumn{3}{|c|}{ TFN } \\
\hline & $\mathrm{C}$ & $\mathrm{A}$ & B \\
\hline P1 & 7.00 & 8.50 & 10.0 \\
\hline $\mathrm{P} 2$ & 7.67 & 9.17 & 10.67 \\
\hline P3 & 7.73 & 9.23 & 10.73 \\
\hline $\mathrm{P} 4$ & 8.07 & 95.67 & 11.07 \\
\hline P5 & 7.47 & 8.97 & 10.47 \\
\hline P6 & 7.60 & 9.10 & 10.6 \\
\hline P7 & 7.00 & 8.50 & 10.00 \\
\hline P8 & 7.2 & 8.70 & 10.20 \\
\hline P9 & 7.67 & 9.17 & 10.67 \\
\hline P10 & 7.13 & 8.64 & 10.13 \\
\hline P11 & 7.47 & 8.97 & 10.47 \\
\hline P12 & 7.27 & 8.77 & 10.27 \\
\hline P13 & 7.47 & 8.97 & 10.47 \\
\hline P14 & 7.40 & 8.90 & 10.4 \\
\hline $\mathrm{P} 15$ & 7.47 & 8.97 & 10.47 \\
\hline P16 & 7.67 & 12.67 & 10.67 \\
\hline $\mathrm{P} 17$ & 7.93 & 9.43 & 10.93 \\
\hline P18 & 7.80 & 93.0 & 10.80 \\
\hline $\mathrm{P} 19$ & 7.73 & 9.23 & 10.73 \\
\hline $\mathrm{P} 20$ & 7.27 & 8.77 & 10.27 \\
\hline $\mathrm{P} 21$ & 7.60 & 9.10 & 10.60 \\
\hline $\mathrm{P} 22$ & 7.60 & 9.10 & 10.60 \\
\hline $\mathrm{P} 23$ & 7.67 & 9.17 & 10.67 \\
\hline $\mathrm{P} 24$ & 7.13 & 8.63 & 10.13 \\
\hline $\mathrm{P} 25$ & 7.33 & 8.83 & 10.33 \\
\hline P26 & 7.73 & 9.23 & 10.73 \\
\hline P27 & 7.33 & 9.23 & 10.73 \\
\hline
\end{tabular}

Hasil perhitungan nilai Servqual (gap) secara keseluruhan dari selisih tingkat persepsi dan harapan menunjukkan sampai sejauh mana pihak PT. ASDP Cabang Sibolga telah memberikan pelayanan sesuai dengan keinginan penumpangnya.

Tabel 3. Nilai servqual (Gap) perdimensi antara persepsi dan harapan penumpang

\begin{tabular}{|c|c|c|c|c|c|}
\hline No & Dimensi Servqual & Persepsi & Harapan & Gap & Rank \\
\hline & Tangibles & & & & \\
\hline 1 & Pelabuhan memiliki fasilitas yang memadai & 9.45 & 9.25 & & \\
\hline 2 & Tempat duduk ruang tunggu penumpang memiliki tempat yang luas, dan memadai & 9.05 & 9.92 & & \\
\hline 4 & Tersedianya loket untuk menginformasikan pembelian tiket dan rute perjalanan & 10.45 & 6.57 & & \\
\hline 5 & Tersedianya area parkir kendaraan yang aman dan nyaman & 9.85 & 9,72 & & \\
\hline 8 & Adanya pembatas antara penumpang wanita dan penumpang pria & 10.12 & 9.45 & & \\
\hline 9 & Tersedianya toilet, musholla, yang nyaman dan bersih & 8.18 & 9.92 & & \\
\hline \multirow[t]{3}{*}{10} & Tersedianya kafe untuk melayani kebutuhan makanan dan minuman bagi penumpang & 9.45 & 9.37 & & \\
\hline & Jumlah & 9.50 & 9.33 & 0.17 & 2 \\
\hline & Reliability & & & & \\
\hline 11 & Pelayanan petugas ticketing cepat, tepat dan ramah & 9.32 & 9.72 & & \\
\hline \multirow[t]{3}{*}{15} & $\begin{array}{l}\text { Petugas pelabuhan dan seluruh crew lainnya membantu jika ada permasalahan } \\
\text { penumpang }\end{array}$ & 9.38 & 9.72 & & \\
\hline & Jumlah & 17.32 & 9.67 & 7.65 & 1 \\
\hline & Responsiveness & & & & \\
\hline 16 & Petugas pelabuhan segera membantu saat melihat penumpang mengalami kesulitan & 9.58 & 11.67 & & \\
\hline 17 & $\begin{array}{l}\text { Kecepatan dan ketepatan petugas dalam memberikan informasi yang diutuhakn } \\
\text { penupang }\end{array}$ & 9.52 & 10.18 & & \\
\hline
\end{tabular}




\begin{tabular}{|c|c|c|c|c|c|}
\hline 18 & Petugas tanggap menjawab pertayaan penumpang & 9.38 & 51.9 & & \\
\hline \multirow[t]{3}{*}{19} & Petugas menyelesaikan keluhan atau masalah dengan cepat & 9.32 & 9.98 & & \\
\hline & Jumlah & 9.45 & 20.93 & 11.48 & 5 \\
\hline & Empathy & & & & \\
\hline 20 & Petugas memberikan waktu pelayanan yang cukup kepada penumpang & 9.32 & 9.52 & & \\
\hline 21 & $\begin{array}{l}\text { Petugas pelabuhan memberikan pelayanan sesuai keinginan dan kebutuhan } \\
\text { penumpang }\end{array}$ & 8.58 & 9.85 & & \\
\hline 22 & Petugas memperhatikan sungguh-sungguh terhadap kebutuhan penumpang & 9.18 & 9,85 & & \\
\hline 23 & $\begin{array}{l}\text { Petugas tidak memandang status sosial dan meperlakukan penumpang dengan sopan } \\
\text { dan hormat }\end{array}$ & 10.05 & 9.92 & & \\
\hline 24 & Petugas mendengarkan keluhan penumpang serta memberikan solusi & 9.58 & 9.38 & & \\
\hline \multirow[t]{3}{*}{25} & Petugas bersikap ramah dan sopan & 10.18 & 9.58 & & \\
\hline & Jumlah & 9.48 & 9.68 & -0.20 & 4 \\
\hline & Assurance & & & & \\
\hline 26 & $\begin{array}{l}\text { Petugas mempunyai skill dan pengetahuan dalam menjalankan tugasnya sehingga } \\
\text { mampu melayani penumpang dengan baik }\end{array}$ & 9.98 & 9.98 & & \\
\hline \multirow[t]{2}{*}{27} & Petugas melayani dengan sikap meyakinkan sehinggga penumpang merasa nyaman & 9.88 & 9.98 & & \\
\hline & Jumlah & 9.93 & 9.98 & -0.05 & 3 \\
\hline
\end{tabular}

Peran gap keseluruhan akan memberikan informasi seberapa besar tingkat kepentingan dan seberapa jauh peran kriteria tersebut dalam tingkat kualitas pelayanan.

Tabel 4. Perhitungan Nilai Servqual (Gap) Keseluruhan

\begin{tabular}{|l|l|l|l|l|}
\hline \multicolumn{1}{|c|}{ Rank } & \multicolumn{1}{c|}{ Dimensi } & \multicolumn{1}{c|}{ Persepsi } & \multicolumn{1}{c|}{ Harapan } & \multicolumn{1}{c|}{ Gap } \\
\hline 1 & Reliabilty & 17.32 & 9.67 & 7.65 \\
\hline 2 & Tangibles & 9.60 & 9.33 & 0.27 \\
\hline 3 & Assurance & 9.93 & 9.98 & -0.05 \\
\hline 4 & Empahty & 9.48 & 9.68 & -0.20 \\
\hline 5 & Responsiveness & 9.45 & 20.93 & -11.48 \\
\hline \multicolumn{2}{|c|}{ Total } & 55.78 & 59.59 & -3.81 \\
\hline
\end{tabular}

Berdasarkan ketentuan nilai gap yaitu :

1. Jika gap positif (Persepsi > Harapan) maka layanan dikatakan "surprise" dan memuaskan.

2. Jika gap nol (Pesepsi = Harapan) maka dikatakan berkualitas dan memuaskan.

3. Jika gap negatif (Persepsi < Harapan) maka layanan dikatakan tidak berkualitas dan tidak memuaskan.

\section{Kesimpulan}

Kesimpulan dari penelitian :

1. Hasil perhitungan gap secara keseluruhan menunjukkan bahwa nilai gap negatif yaitu -3.81yang berarti bahwa apa yang diharapkan penumpang belum semua sesuai dengan apa yang diperoleh penumpang di PT.ASDP Cabang Sibolga. Maka layanan yang diberikan PT. ASDP Cabang Sibolga dikatakan tidak berkualitas dan tidak memuaskan.

2. Sistem yang dibangun masih bersifat desktop menghasilkan laporan bersifat rekomendasi hanya dapat digunakan untuk kebutuhan PT.ASDP Cabang Sibolga.

\section{Daftar Pustaka}

[1] H. Sholikah and S. W. Iriananda, "Analisis Kepuasan Pelanggan Travel Menggunakan Metode Fuzzy Service Quality," JOINTECS (Journal Inf. Technol. Comput. Sci., vol. 2, no. 2, 2017, doi: 10.31328/jointecs.v2i2.468.

[2] N. Chaniago and A. Sindar, "SPK Penilaian Hasil Belajar Siswa Menggunakan Metode TOPSIS," vol. 9, pp. 41-48, 2020.

[3] E. Sutinah and O. R. Simamora, "Metode Fuzzy Servqual Dalam Mengukur Kepuasan Pasien Terhadap Kualitas Layanan BPJS Kesehatan,” J. Inform., vol. 5, no. 1, pp. 90-101, 2018, doi: 10.31311/ji.v5i1.2944.

[4] S. P. Astuti et al., "Fuzzy - servqual," J. Ilm. Tek. Ind., vol. 4, no. 1, p. 27, 2015,

[5] N. F. Kartika, "Implementasi Fuzzy - Service Quality Terhadap Tingkat Kepuasan Layanan Mahasiswa Implementation of Fuzzy - Service Quality for Student Service Level of Satisfaction," J. Ilm. SISFOTENIKA, vol. 7, no. 1, pp. 38-49, 2017.

[6] A. B. Yushila, M. Effendi, and U. Effendi, "Analisis Kepuasan Konsumen dengan Metode Fuzzy Servqual dan Quality Function Deployment (Studi Kasus Cafe Right Time Malang),” J. Teknol. Pertan., vol. 18, no. 2, pp. 107-118, 2017. 
[7] A. S. RM. Sinaga "Binary Image Object Identification Using Fuzzy Logic and Labeling Breadh-First," vol. 6, no. 4, 2018.

[8] L. Futiami and S. Anita, "Penentuan Supplier Bahan Baku Restaurant XO Suki Menggunakan Metode Weight Product," vol. 2, no. April, pp. 1-4, 2019.

[9] Aminullah, A. and Abdullah., The Impact Of Baraya Travel's Quality of Services On Customer Satisfaction In Bandung. Universitas Telkom., 2016.

[10] H. R. Triyastuti.,W.,Agus,.R., Analisis Kualitas Pelayanan Dengan Menggunakan Fuzzy Servqual, Kuadran IPA, Dan Indeks PGCV. Jurnal Gaussian., Volume 4, Nomor 4, Tahun 2015, Halaman 885 - 894. 2015 